\title{
Redang Island in the Eyes of International Tourist
}

\author{
N Alia Fahada W Ab Rahman, Monizaihasra Mohamed, Farizah Sulon, \\ Mohd Roslan Rosnon, Azreen Jihan Che Mohd Hashim
}

To Link this Article: http://dx.doi.org/10.6007/IJARBSS/v11-i3/8670

DOI:10.6007/IJARBSS/v11-i3/8670

Received: 27 January 2021, Revised: 24 February 2021, Accepted: 06 March 2021

Published Online: 16 March 2021

In-Text Citation: (Rahman et al., 2021)

To Cite this Article: Rahman, N. A. F. W. A. M. M., Sulon, F., Rosnon, M. R., \& Hashim, A. J. C. M. (2021). Redang Island in the Eyes of International Tourist. International Journal of Academic Research in Business and Social Sciences, 11(3), 522-531.

Copyright: (c) 2021 The Author(s)

Published by Human Resource Management Academic Research Society (www.hrmars.com)

This article is published under the Creative Commons Attribution (CC BY 4.0) license. Anyone may reproduce, distribute, translate and create derivative works of this article (for both commercial and non-commercial purposes), subject to full attribution to the original publication and authors. The full terms of this license may be seen

at: http://creativecommons.org/licences/by/4.0/legalcode

Vol. 11, No. 3, 2021, Pg. 522 - 531

Full Terms \& Conditions of access and use can be found at http://hrmars.com/index.php/pages/detail/publication-ethics 


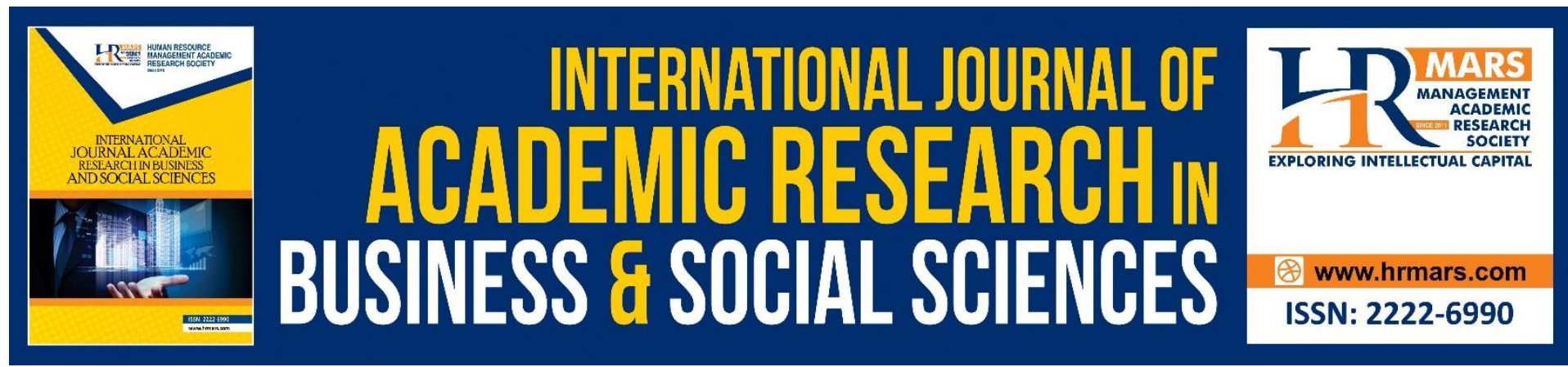

\title{
Redang Island in the Eyes of International Tourist
}

\author{
N Alia Fahada W Ab Rahman', Monizaihasra Mohamed², \\ Farizah Sulong3, Mohd Roslan Rosnon ${ }^{4}$, Azreen Jihan Che \\ Mohd Hashim ${ }^{5}$ \\ 1,2,3 School of Business, Economics and Social Development, Universiti Malaysia, \\ Terengganu,21030 Kuala Nerus, Terengganu, Malaysia. ${ }^{4}$ Department of Social \& \\ Development Sciences, Faculty of Human Ecology, Universiti Putra Malaysia, 43400 UPM, \\ Serdang, Selangor, Malaysia ${ }^{5}$ Faculty of Economics and Muamalat, Universiti Sains Islam \\ Malaysia, Bandar Baru Nilai, 71800, Nilai, Negeri Sembilan, Malaysia \\ Email:n.alia@umt.edu.my
}

\begin{abstract}
This study investigates Tripadvisor as manifestation of tourist experience. The tourist experience posted on TripAdvisor were analysed to gain insight of the destination experience being expressed. The content was analysed to discover what tourists were communicating about their experience in Redang. Results revealed that major strength of the destinations were its activities, natural resources, and infrastructure while international tourists' experience with environment is mixed of positive and negative comments. This study demonstrated that TripAdvisor as an established travel reviews are an inexpensive means to collect authentic and spontaneous tourist view. This source also served as an cost-effective ways for destination marketers to understand their service quality and enhance the tourist satisfaction.
\end{abstract}

Keywords: TripAdvisor, Redang Island, Destination Marketing, Tourist Experience.

\section{Introduction}

With the advancement of Internet technologies and the extensive use of user generated content including travel reviews, the eWord of Mouth (eWOM) has become easily and widely available. The use of travel reviews sites has gained extensive attention from tourism researchers which covers broad topics (Leung et al., 2013). For example, researchers have evidence that the user-generated content (UGC) provide a significant source to understand tourist behaviour (Bosangit, 2012), destination attributes (Li \& Wang, 2011) and as an effective marketing tool (Pan et al., 2007). The growth of internet technologies has enabled tourists to share their experience, onions and feelings about tourism product and services online. Consequently, the eWOM widen the tourists' selections for gathering information about a destination. Also, the online atmosphere allows tourists to exchange their opinion and discuss about tourism product and services by expressing them in travel reviews or blogs (Schinler and Bickart, 2005). Other than provide a place for tourists to share their touristic experience, eWOM also shaped the tourist's decision-making process by reducing the uncertainty and risk related to hospitality consumption that involves an intensive information 
search because tourists considered eWOM as a reliable source of information (Filieri, 2015; Filieri \& McLeay, 2014).

Of the studies that exist on island destination, limited studies have considered to understand the communicated aspects of the Malaysian island, including Redang Island. Existing studies that examined eWOM of Malaysia Island as a tourist destination are limited. Previous studies mainly focussed on questionnaires surveys that focussed on tourist satisfaction (Aliman et al., 2014a; Aliman et al., 2016; Mohamad et al.2012), destination image and trip behaviour (Aliman et al., 2004b) and destination competitiveness (Zainuddin et al., 2016). The objectives of this study are dual. First, it aims to provide an understanding of travel reviews as expression of tourist experience. Second, this study purposes to provide insight how the tourist's experience posted online is a source to understand the experience communicated about a specific destination. The study will be showed that travel reviews are not only a cost-effective source of tourist's opinion and feedback, but also serve as a service quality control mechanism.

\section{Literature Review eWOM}

The significance of word of mouth in the tourism and hospitality has risen with the advent of Internet technology and social media which is associated with UGC (Buttle, 1998). Reviews and comments posted on UGC is considered alike to recommendation from family and friends and thus associated with eWOM (Wang, Yu \& Fesenmeier,2002; Tham, Croy \& Mair, 2013). The growth of UGC role in information dissemination, gathering and exchange has attracted researchers interest in conducting research within UGC and tourism and hospitality. For instance, UGC has become the primary source of understanding tourist experience, tourism consumption and destination image (Bosangit et al. 2012; Pan et al., 2007; Sangkaew \& Zhu, 2020). Online travel reviews, for example has been increasingly considered as a source for destination marketers to improve their tourism product and marketing strategies. This is due to the nature of travel reviews that are more reliable and easy to understand (Zhang \& Sun, 2017). Online reviews that usually consisted of both negative and positive reviews is seen as influential in travel decision making (Zhang \&Sun, 2017; Tse \& Zhang, 2013).

\section{TripAdvisor}

TripAdvisor is a website that enable tourist to write review of destination. Tourists must create an account which enable them to post reviews, comments, ratings on destination, hotel, attraction or tourism product or services. In terms of content, in tourist can upload photos and videos and also textual content in TripAdvisor. Reviews were gathered from TripAdvisor, because it is the main site among online travel research results (Xiang \& Gretzel,2010).

\section{Redang Island}

Redang Island is undeniably one of the most attractive islands in Malaysia with turquoise blue waters and richness of spectacular of marine life. Geographically, Redang Island is located in the South China Sea off the East Coast of Peninsular Malaysia (Latitude $5^{\circ} 44^{\prime} \mathrm{N}-5^{\circ} 50^{\prime} \mathrm{N}$ and

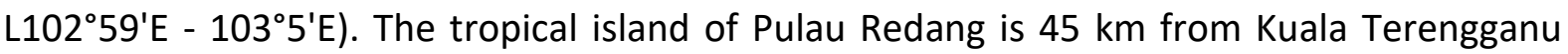
(Tourism Malaysia, 2018). It is the largest island, measuring by 7 kilometers long and 6 kilometers wide (Fisher, Nawaz, Fauzi, Nawaz, Sadek, Latif \& Blackett, 2008). According to 
Tourism Malaysia (2009), Redang Island is a paradise for swimming, snorkeling and scuba diving. Other activities that can be enjoyed include jungle trekking, boating and canoeing. Remarkably, every dive in this island offers something different to experience, feel and see.The Redang Islands are composed of many other islands, where Redang Island is the main land and the one offer resort and chalet facilities. Other islands include; Ling Island, Kerengga Kecil Island, Kerengga Besar Island, Pinang Island, Ekor Tebu Island, Lima Island, Paku Kecil Island and Paku Besar Island. However, these islands are uninhabited like Redang Island (Tourism Malaysia, 2018). Travel to Redang Island from Merang with a tourist boat, takes between 45 minutes and 1 hour and half. It also depends on the speed boat, the weather and the tidal currents. However, if tourits take ferry ride from the Bandar Jeti Shah, Kuala Terengganu, it takes 2 hours to 2 and a half hours.

\section{Methodology}

Data Collection. The reviews selected for this study is reviews posted for the time period of September 2016 until September 2018 with the following search keywords:'Redang Island' and 'Redang'. More than 300 reviews were identified. Three selection criteria were applied to the reviews selection. First, only reviews written in English were chosen, due to the researcher's familiarity with the language. Second, reviews that specifically related to certain accommodation, such as hotel and resorts were withdraw from the selection due to this study aims to investigate about the Redang Island as a whole rather than specifically focussed on the specific product or services. Third, only reviews that written in more than two sentences were selected. This to ensure that the reviews have significant meaning of tourist experience. For the first two selection criteria, 205 reviews were selected. Then the reviews were screen to select the reviews that posted by international tourists. The identification of the local and international tourist can be identified through their profile. It is clearly stated in their profile where are their origin through country they are residing. Based on this selection criteria, 120 reviews were selected.

Data Analysis. The text from the collected reviews was analysed using Atlas.ti 8.0 (Berlin, Germany). Several data cleaning were performed on the textual data before using the Atlas.ti software (Choi et al., 2007; Stepchenkova \& Morrison, 2006). Given that the objective of this study is to unfold the communicated aspects of tourist experience, this study used a qualitative content analysis method. Content analysis is defined as a method used to excerpt desired data from material by systematically identifying specified characteristics (Smith 2010). Content analysis has been employed in most studies examining tourism related online reviews (see for example, Li \& Wang, 2011; Lei \& Law 2015). The data were analysed by using the following steps:

(1) The substantial statements of the textual data were underlined, and the unrelated statements were removed

(2) Codes were developed from the statement

(3) The formulated codes were clustered into common themes and labelled

(4) The themes were then combined with the codes

\section{Findings and Discussions}

Following the selection criteria, 120 reviews of international tourist were selected. The demographic information of the reviewers was gathered from the profile of the account. The users can share information such as location and the period of they since be a member. All 
the reviews show a clear identity of the tourists. The identification of the international tourist can be identified through their profile. It is clearly stated in their profile where are their origin through country they are residing. Most of the reviews come from tourists who travel with family It is identify through the word use such as "our kids", "my family", "daughters" and "sons". The average stayed is 3 nights.

Four broad classification of themes were derived from the analysis, namely tourist activities, natural resources, infrastructure, and environment. The content analysis generated 12 attributes that exemplify four categories relating to tourist activities, natural resources, infrastructure, and environment (Fig. 1). Most of the emerged attributes are consistent with attributes observed in past studies (Echtner \& Ritchie, 2003).

Table 1. Emerging attributes

\begin{tabular}{|c|c|c|c|}
\hline Super families & Code families & Description & Quotation \\
\hline \multirow[t]{2}{*}{ Tourist Activities } & Leisure activities & $\begin{array}{l}\text { walking around, } \\
\text { swimming }\end{array}$ & \multirow[b]{2}{*}{$\begin{array}{l}\text { "Redang Island is still } \\
\text { untouched and } \\
\text { immaculate. We } \\
\text { spent } 2 \text { weeks on the } \\
\text { island and enjoyed } \\
\text { snorkeling trips and } \\
\text { jungle walks. } \\
\text { Beautiful and } \\
\text { healthy corals, lot of } \\
\text { fish (sharks, turtles, } \\
\text { eels, rays, etc). On } \\
\text { the land beatiful and } \\
\text { wild landscape (it } \\
\text { looks like visiting a } \\
\text { botanical gardens } \\
\text { with lot of different } \\
\text { species of plants and } \\
\text { trees, not to } \\
\text { mention wildlife as } \\
\text { monkeys, monitor } \\
\text { lizards, butterflies, } \\
\text { sea eagles" }\end{array}$} \\
\hline & Adventure activities & $\begin{array}{l}\text { scuba diving, } \\
\text { snorkeling }\end{array}$ & \\
\hline \multirow[t]{3}{*}{ Natural resources } & Scenery & $\begin{array}{l}\text { Beautiful beach, } \\
\text { windy trees }\end{array}$ & \multirow{3}{*}{$\begin{array}{l}\text { "Beautiful } \\
\text { archipelago. Water } \\
\text { is clean, blue and } \\
\text { clear. The weather } \\
\text { was pretty hot but } \\
\text { manageable. One of } \\
\text { the things we really } \\
\text { enjoyed was the } \\
\text { private snorkelling } \\
\text { trip to Pulau Lima. } \\
\text { This was my first I }\end{array}$} \\
\hline & Weather & $\begin{array}{l}\text { nice, fresh air, } \\
\text { sunset, }\end{array}$ & \\
\hline & Marine life & turtle, fishes, corals & \\
\hline
\end{tabular}




\begin{tabular}{|c|c|c|c|}
\hline & & & $\begin{array}{l}\text { admit. And it was } \\
\text { beyond } \\
\text { expectations". }\end{array}$ \\
\hline \multirow[t]{3}{*}{ Infrastructure } & Accommodation & $\begin{array}{l}\text { Distance to beach, } \\
\text { price }\end{array}$ & \multirow[b]{3}{*}{$\begin{array}{l}\text { "If you want to } \\
\text { escape from the } \\
\text { busy town this is the } \\
\text { island you should } \\
\text { choose. The place } \\
\text { can be easily } \\
\text { accessible by boat } \\
\text { from Merang Jetty, } \\
\text { travel will take less } \\
\text { than } 30 \text { mins, and lot } \\
\text { of boats, just book } \\
\text { one from your hotel. } \\
\text { You will need to pay } \\
\text { 30RM for entry to } \\
\text { the island @ ferry. } \\
\text { The water is so clear, } \\
\text { you can do } \\
\text { snorkelling, and } \\
\text { swim with the big } \\
\text { turtles. The sun can } \\
\text { be very intense at } \\
\text { the beach, so be } \\
\text { careful not to get sun } \\
\text { burn." }\end{array}$} \\
\hline & Transportation & $\begin{array}{l}\text { travel arrangement, } \\
\text { cost, }\end{array}$ & \\
\hline & General infrastructure & $\begin{array}{l}\text { police station, health } \\
\text { centre }\end{array}$ & \\
\hline \multirow[t]{4}{*}{ Environment } & Crowdedness & pack with tourists & \multirow{4}{*}{$\begin{array}{l}\text { "The beach is very } \\
\text { crowded by very } \\
\text { noisy people, if you } \\
\text { are looking for a } \\
\text { place where you can } \\
\text { relax under the } \\
\text { shade of palms this is } \\
\text { not the place!" }\end{array}$} \\
\hline & Pollution & noise, damage corals & \\
\hline & Calm & relax, peaceful & \\
\hline & Beach quality & clean, white sand & \\
\hline
\end{tabular}

\section{Tourist Activities}

Tourist recorded many activities in which they participated and watched. All these activities are categorized into two: leisure and adventure activities. Leisure activities mentioned by the tourists were walking along the beach, swimming with the fish, snorkelling. Majority of the tourists were satisfied with the scuba and snorkelling package booked from the tour operators. Most of the tourist enjoy walking along the beach. While performing this activity, the tourist enjoyed the nature of the island. For example, they praised the "white sand", "crystal clear water" and "beautiful island". Tourists also expressed an interest in adventure activities such as scuba dive jungle tracking and hiking. 


\section{Natural Resources}

In expressing their tourist experience, Redang's natural resources also highlighted by the international tourists. The island is a major attraction for the tourists. Beerli and Martin (2004) describe natural resources are include weather, flora and fauna. Positive comments were mostly found related to the natural resources. The environment of Redang Island was perceived as "beautiful beach", "amazing" and "fantastic. Tourists were particularly touched by the white sand, clear water and blue sky of Redang Island. Redang Island has many unique fauna, especially marine life. Tourists enjoyed and remarked on the "coloured fishes", "friendly turtle", and "amazing coral reefs". Tourists that enjoyed snorkelling, scuba diving and swimming have greater access to variety of natural resources compared to those who did not.

\section{Infrastructure}

The most communicated aspects of infrastructure talked by the international tourist about Redang Island is accommodation. Tourist specifically mentioned the resorts' name and highlighted the most things they like or does not like about the accommodation. Accommodation quality, price and location is highlighted. Quality including the rooms, food and staff friendliness are highlighted by them in sharing their experience about the accommodation. To describe location, they usually describe it with the distance from the beach. This reflects that, in reviewing and selecting their accommodation, these two aspects are important which reflects their decision making and satisfaction. Other than that, tourists also mentioned the general infrastructure at the island, such as police station and health centre. This shows that these two infrastructures is significant for them during their stay.

Transportation is a central component of the tourist experience (Pearce, 1982). International tourists were found to express "how to get there" including timing and cost. The sharing of the factual information is not only reflecting the important of such information for others, but also serve as a tip for the readers. The suggestion and recommendation about the transportation reflects the transportation arrangement for island tourists is crucial. The options available also were highlighted and the justification of their decision is also found. Much of their experience with the transportation was delightful, as no negative expression is expressed. The word "easy" is mostly used to describe their transportation arrangement and mostly it is associated with the accommodation, whereby the arrangement is made through the booked hotel or resorts.

\section{Environment}

International tourists consider Redang Island is pack with tourists and therefore, pollution was highlighted. Pollution such as noise and damage corals reflect their negative tourist experience which created tense to them. In addition, tourists also gave suggestion to the authority to improve and protect the natural environment. This shows that international tourists were concern about Redang Island sustainability. However, despite the negative comments, Redang Island also considered a peaceful and a suitable destination for tourist to unwind as they appreciate the natural environment, such as the beach quality and authenticity. 


\section{Conclusions and Implication for Future Research}

The purpose of the current study is to investigate the most communicated aspects of Redang Island. The findings shown that the online reviews about Redang Island posted on TripAdvisor reflected various aspects of tourists' experiences in Redang Island, from activities, attractions to overall opinions. Also, international tourists visited Redang Island communicated their experience about the island based on the tourist activities, natural resources, infrastructure, and environment which consists of combination of positive and negative experience. Positive experience was mostly reported in three elements: activities, natural resources, and infrastructure while a mixed of positive and negative experience were found in environment. Crowdedness, pollution, and noise were most highlighted by the tourists, thus indicates that improvement should be done by the authorized body.

As the reviews consists of positive and negative experience, it thus reflected the strengths and weaknesses of Redang Island. Recognizing the strengths and weaknesses of a destination can provide a significant recommendation for destination marketers. For instance, tourist activities is considered the strength of Redang Island as most tourists wrote positive experience that covers a wide range of activities. Thus, marketers need to promote Redang Island with a multi-dimension of tourists activities. Despite the positive reviews, international tourists complaints about the environment especially on the pollutions. Thus, this area need to be improved to maintain Redang Island sustainability.

In addition, the study revealed that analysing online reviews that rich of touristic experience can help destination marketers to obtained reliable information that scarcely found in other sources. Further, the rich information can help tourism product development and marketing. For example, some tourist mentioned about the moderate level of food at the island. "Beautiful archipelago. Water is clean, blue and clear. The weather was pretty hot but manageable. One of the things we really enjoyed was the private snorkelling trip to Pulau Lima. This was my first I admit. And it was beyond my expectations. The only real problem was food. Wherever we went it was okayish but nothing spectacular". Therefore, the potential of travel reviews as a useful marketing tools should draw marketers' attention.

For further research, it is suggested that a different view can be observed, from two different sample, domestic and international tourists. By acknowledging these two different samples can make it clearer to which aspects of Redang Island is appreciated or communicated most by the domestic or international tourists. Also, knowing the communicated aspects of Redang Island by specific demographic or location may allow a more specific marketing campaign can be applied, thus allowing a more realistic impact towards the campaign. This study discovers the most communicated aspects of Redang Island. However, the insights of the aspects are not studied. Further studies need to be done to understand the meaning of the tourist experience expressed by the tourists. A deep understanding of the tourist experience will allow a better understanding of a specific destination. In terms of methodology, future studies might consider adopting a more time effective methodology. With the advancement of technology, for instance, netnography (ethnography applied to the internet) can be used. It is a less time-consuming method to gather online data and allow the researchers an opportunity to gather interpretive data of the meaning lived by tourists (Woodside et al., 2007; Woodside, 2009). 


\section{Acknowledgement}

Universiti Malaysia Terengganu supports this work under the research grant entitled Talent and Publication Enhancement - Research Grant (TAPE-RG - 55144).

\section{References}

Aliman, N. K., Hashim, S. M., Wahid, S. D. M., \& Harudin, S. (2014a). Tourist expectation, perceived quality and destination image: Effects on perceived value and satisfaction of tourists visiting Langkawi Island, Malaysia. Asian J. Bus. Managment 2(1), 212-222.

Aliman, N. K., Hashim, S. M., Wahid, S. D. M., \& Harudin, S. (2014b). The effects of destination image on trip behavior: Evidences from Langkawi Island, Malaysia. European Journal of Business and Social Sciences, 3(3), 279-291

Aliman, N. K., Hashim, S. M., Wahid, S. D. M., \& Harudin, S. (2016), Tourists' satisfaction with a destination: an investigation on visitors to Langkawi Island. International Journal of Marketing Studies, 8(3), 173-188

Beerli, A., \& Martin, J. D. (2004). "Factors Influencing Destination Image." Annals of Tourism Research, 31 (3): 657-81

Bosangit, C. (2012). Understanding consumption experiences: A discourse analysis of travel blogs. Unpublished PhD's tesis. Nottingham University

Bryman, A. (2012). Social research methods (4th ed.). Oxford: Oxford University Press.

Chen, G. M. (2011). Tweet this: A uses and gratifications perspective on how active Twitter use gratifies a need to connect with others. Computers in Human Behavior, 27(2), 755762. doi:10.1016/j.chb.2010.10.023

Choi, S., Lehto, X. Y., \& Morrison, A. M. (2007). Destination image representation on the web: Content analysis of Macau travel related websites. Tourism Management, 28, 118-129.

Filieri, R. (2015) What makes online reviews helpful? A diagnosticity-adoption framework to explain informational and normative influences in e-WOM. Journal of Business Research 68(6): 1261-1270.

Filieri, R., \& McLeay, F. (2014) E-WOM and accom- modation an analysis of the factors that influ- ence travelers' adoption of information from online reviews. Journal of Travel Research 53(1): 44-57

Fisher, J. B., Nawaz, R., Fauzi, R., Nawaz, F., Said Md Sadek, E. S., Abd Latif, Z., and Blackett, M. (2008). Balancing water, religion and tourism on Redang Island, Malaysia. Environmental Research Letters, 3(2), 024005. doi:10.1088/17489326/3/2/024005.

Huang, C.-Y., Shen, Y.-Z., Lin, H.-X., \& Chang, S.-S. (2007). Bloggers' motivations and behaviors: A model. Journal of Advertising Research, 47(4), 472-484. doi: $10.2501 / \mathrm{S} 0021849907070493$

Li, D. (2005). Why do you blog: A uses-and-gratifications inquiry into bloggers' motivations. Unpublished master's tesis, Marquette University.

Lin, Y.-S., \& Huang, J.-Y. (2006). Internet blogs as a tourism marketing medium: a case study. Journal of Business Research, 59 1201-1205. doi:10.1016/j.jbusres.2005.11.005

Liu, S.-H., Liao, H.-L., \& Zeng, Y.-T. (2007). Why people blog: an expectancy theory analysis. Issues in Information Systems, 8(2), 232-237.

Liu, S.-H., Liao, H.-L., \& Zeng, Y.-T. (2007). Why people blog: an expectancy theory analysis. Issues in Information Systems, 8(2), 232-237.

Lei, S., \& Law, R. (2015). Content analysis of TripAdvisor reviews on restaurants: A case study of Macau. Journal of Tourism, 16(1), 17-28. 
Leung, D., Law, R., van Hoof, H., \& Buhalis, D. (2013). Social media in tourism and hospitality: A literature review. Journal of Travel \& Tourism Management, 30(1-2), 3- 22.

Mohamad, M., Abdullah, A. R., \& Mokhlis, S. (2012). Tourists' evaluation of destination image and future behavioural intention: The case of Malaysia. Journal of Management and Sustainability, 2(1), 181- 189

Mura, P. (2015). Perceptions of authenticity in a Malaysian homestay-A narrative analysis. Tourism Management, 51, 225-233.

Pan, B., Maclaurin, T., \& Crotts, J. C. (2007). Travel blogs and the implications for destination marketing Journal of Travel Research, 46, 35-45. doi: 10.1177/0047287507302378

Pearce, P. L. (1982). The social psychology of tourist behaviour. Oxford, United Kingdom: Pergamon.

Pühringer, S., \& Taylor, A. (2008). A practitioner's report on blogs as a potential source of destination marketing intelligence. Journal of Vacation Marketing 14(2), 177-187. doi: $10.1177 / 1356766707087524$

Sangkaew, N., \& Zhu, H. (2020). Understanding Tourists' Experiences at Local Markets in Phuket: An Analysis of TripAdvisor Reviews, Journal of Quality Assurance in Hospitality \& Tourism, DOI: 10.1080/1528008X.2020.1848747

Stepchenkova, S., \& Morrison, A. M. (2006). The destination image of Russia: From the online induced perspective. Tourism Management, 27, 943-956.

Schmidt, J. (2007). Blogging practices: An analytical framework. Journal of ComputerMediated Communication, 12(4), 1409-1427. doi:10.1111/j.1083-6101.2007.00379.x

Schinler, R. M., Bickart, B. (2005). Published Word of Mouth: Referable, Consumer- Generated Information on the Internet. Online Consumer Psychology: Understanding and Influencing Consumer Behavior in the Virtual World. Lawrence Erlbaum Associates, Inc, NJ.

Tham, A. G. J., Croy, G., \& Mair, J. (2013). Social media in destination choice: Distinctive wordof-mouth dimensions. Journal of Travel and Tourism Marketing, 30(1/2), 144-155

Tse, T. S., \& Zhang, E. Y. (2013). Analysis of Blogs and Microblogs: A Case Study of Chinese Bloggers Sharing Their Hong Kong Travel Experiences. Asia Pacific Journal of Tourism Research, 18(4), 314-329.

Wang, Y., \& Fesenmaier, D. R. (2004). Modeling participation in an online travel community. Journal of Travel Research, 42(3), 261-270. doi: 10.1177/0047287503258824

Xiang, Z., \& Gretzel, U. (2010). Role of social media in online travel information search. Tourism Management, 31 (2), 179-188. doi:10.1016/j.tourman.2009.02.016

Zhang, Y., \& Hitchcock, M. J. (2017). The Chinese female tourist gaze: a netnography of young women's blogs on Macao. Current Issues in Tourism, 20(3), 315-330.

Xu, Li., \& Wang, Y. (2011): China in the Eyes of Western Travelers as Represented in Travel Blogs, Journal of Travel \& Tourism Marketing, 28(7), 689-719

Zainuddin, Z., Radzi, S. M., \& Zahari, M. S. M. (2016). Perceived destination competitiveness of Langkawi island, Malaysia. Procedia-Social and Behavioral Sciences, 222, 390-397. https://doi.org/10.1016/j.sbspro.2016.05.190. 